\title{
逆流風波開水路混成場における 乱流特性に関する研究 TURBULENCE CHARACTERISTICS IN ADVERSE WIND-DRIVEN OPEN-CHANNEL FLOWS
}

\author{
襧津家久 $1 \cdot$ 垂井晃一 $2 \cdot$ 吉田圭介 ${ }^{3}$ \\ Iehisa NEZU, Kouichi TARUI and Keisuke YOSHIDA \\ 1フェロー会員 工博 京都大学大学院教授 社会基盤工学専攻（产606-8501 京都市左京区吉田本町） \\ 2学生員 京都大学大学院修士課程 社会基盤工学専攻 \\ 3学生員 京都大学大学院博士課程 環境地球工学専攻
}

\begin{abstract}
This study describes an experimental investigation on turbulence characteristics and the water-surface fluctuations in adverse wind-driven open-channel flows by using both a laser Doppler Anemometer (LDA) and a wave gauge simultaneously. In this study, it was shown that the velocity fluctuations of water flow near the interface in not only cocurrent flow but also adverse flow are significantly affected by the water surface in every range of frequency. However turbulence characteristics in water layer in adverse wind-driven open-channel flows are different from those in cocurrent flow, and there exists a high correlation between turbulence and the surface fluctuations in predominant frequency due to high-sheared wind flow.
\end{abstract}

Key Words : adverse wind-driven open-channel flows, turbulent characteristic, LDA,

\section{1.はじめに}

水流速が遅く風が速い場所では水面の上を流れる風の 影響を大きく受ける流れ場が数多く存在する. 開水路流 の上に風シアーの加わったこの流れ場は非常に複雑であ り，また自由水面での気体輸送等にも大きな影響を与え る. 現在まで開水路乱流や風波場について数多くの検討 がなされている ${ }^{1,2)}$. 開水路流れの上に風シアーを伴う流 れ場には，空気流と水流の方向が同じ順流場と空気流と 水流の方向が逆である逆流場がある. 著者らはこれまで 順流場において水・空気界面での乱流特性について研究

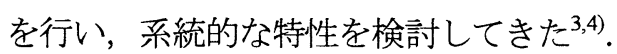

逆流場においては波浪の予測などの点から海岸・海洋 工学の分野で多くの研究がなされている. 鶴谷 ${ }^{5)}$ は波が 立たない弱い風シアーを伴った逆流場において実験を通 じて水流の流速分布や乱れ特性について考察を行ってお り，流速分布や乱れ強度に対して底面シアーによるもの と界面シアーによるものとを線形的に加えることができ ると仮定して経験式を与えた. セリーら”は流れ関数を 用いて順流場および逆流場における主流速特性を予測す る手法を提案している. Rashidi \& Banajeeきは順流場およ
び逆流場において数パターンの実験条件で流速分布や乱 れ特性について示しており，また可視化計測も行ってい る. また, 逆流場での風波についての研究では鶴谷ら ${ }^{8)}$ が波の発達特性についての研究を行っている.

以上，既往の研究は波が立たないような風シアーが弱 い逆流場を扱った研究が多く, 風シアーが強く風波が発 生している流れ場での主流速特性や乱流特性についての 研究はあまり行われていない. また，逆流場における水 層の乱流特性と水面変動に関する考察もあまり行われて いない，そこで本研究では逆流場において系統的に実験 条件を変化させて，水路中央鈆直断面においてレーザー 流速計（LDA）および波高計の同時計測によって，順流 場における乱流特性との比較検討から逆流場における乱 流特性について考察を試みる.

\section{2. 奏験装置および実験条件}

\section{（1）実験水路}

本実験で用いた水路は，全長 $16 \mathrm{~m} ，$ 幅 $40 \mathrm{~cm}$ ，高さ $50 \mathrm{~cm}$ の傾斜水槽風洞である ${ }^{4}$. 図-1に概要図を示す．計 測部は水路風上端より約 $9 \mathrm{~m}$ 地点で，水路両側壁と底 


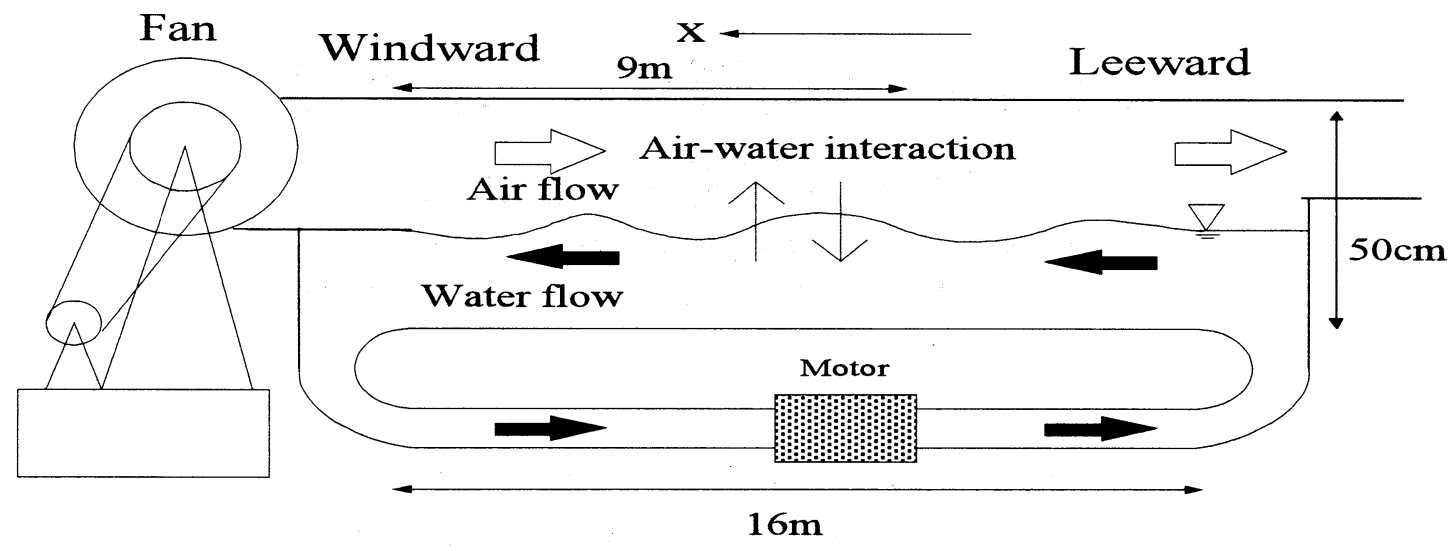

図-1 風洞付き傾斜水槽実験装置

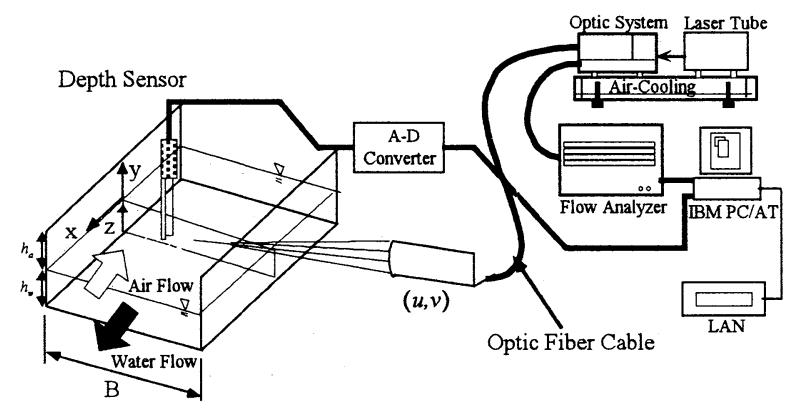

図-2 LDA計測装置と容量式波高計

面が光学ガラス製である.

\section{（2）計測方法および実験条件}

瞬間流速の点計測には，300mWの後方散乱型2成分ア ルゴンイオンレーザー流速計(LDA，Dantec社製)を用い た（図-2）。計測点は水層および空気層それぞれの水路 中央断面とした. 空気流のLDA散乱粒子の直径は平均 $1.5 \mu \mathrm{m}$ ，比重は1.02であり，霧発生装置（Dantec社製）を 用いた. 水流のLDA散乱粒子には市販の水性ペンキを用 いた. LDAのトラバース装置は水路に直付けで $1 / 100 \mathrm{~mm}$ の精度を有する. 測定時間は60秒, 測定周波数は水層で 最大約 $200 \mathrm{~Hz}$, 空気層で最大約 $500 \mathrm{~Hz}$ であった. 座標系 は水路中央断面において, 流下方向に $x$ 軸, 鉛直上向き に静水面から $y$ 軸, 水路底面から上向きに $z$ 軸とした （図-2）. 流下方向 $x$ 軸お上で鈆直方向 $y$ 軸（or $z$ 軸）方向の平均流速成分を $(U, V)$, 乱れ変動成分を $(u, v)$ と定義した。また，容量式波高計（Kenek社製） を設置して流速変動と水面変動の同時計測を行った. そ

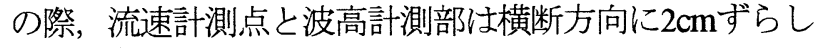
てある ${ }^{4)}$.

実験条件を表-1に示す．なお，ここでは添字 $a, w$ は それぞれ空気層および水層に関する量を示す，本実験で は静水時における水層厚 $h_{w}(=7.0 \mathrm{~cm})$ および空気層厚 $h_{a}(=43.0 \mathrm{~cm})$ を固定し $\left(z=y+h_{w}\right)$, 水路底面は平 坦で滑面とした。本研究では水路アスペクト比
表-1 実験条件表

\begin{tabular}{|l|c|c|c|c|c|c|}
\hline & $\begin{array}{c}U w, \text { mean } \\
(\mathrm{m} / \mathrm{sec})\end{array}$ & $\begin{array}{c}U a, \text { max } \\
(\mathrm{m} / \mathrm{sec})\end{array}$ & $\begin{array}{c}U_{* a} \\
(\mathrm{~cm} / \mathrm{sec})\end{array}$ & $\begin{array}{c}U_{*_{w}} \\
(\mathrm{~cm} / \mathrm{sec})\end{array}$ & $h^{\prime} / h_{w}$ & $\begin{array}{c}f_{p} \\
(\mathrm{~Hz})\end{array}$ \\
\hline REV1 & 0.265 & -1.51 & -4.93 & 1.35 & 0.00545 & - \\
\hline REV2 & 0.262 & -2.19 & -9.53 & 1.33 & 0.00384 & - \\
\hline REV3 & 0.264 & -2.87 & -12.5 & 1.33 & 0.0293 & 1.39 \\
\hline REV4 & 0.260 & -3.54 & -17.6 & 1.29 & 0.0329 & 1.39 \\
\hline REV5 & 0.259 & -4.28 & -20.1 & 1.26 & 0.0459 & 1.29 \\
\hline REV6 & 0.260 & -4.97 & -25.2 & 1.24 & 0.0256 & 1.39 \\
\hline
\end{tabular}

$B / h_{w}=5.7$ （水路幅 $B=40 \mathrm{~cm} ）$, フルード数 $F_{r}=0.2$ の 開水路等流を基本流として, 空気層最大風速 $U_{a, \max }$ を系 統的に調整することで，開水路水面上に逆向きに風シ アーを与え，一連の界面波（REV1～REV6）を発生させ た. $U_{*_{a}}, U_{*_{b}}$ はそれぞれ空気層界面，水層底面での平 均流速に対数則分布を適用して求めた摩擦速度である. また, 風波の卓越周波数 $f_{p}$ は主流速変動 $u(t)$ をLDA 計測した後にスペクトル解析から求めた.なお，REV1, REV2のケースではスペクトル解析で明確な卓越周波数 が観察されなかった.

\section{3. 実験結果および考察}

\section{（1）主流速分布}

図-3は逆流風速下での水層の平均流速 $U_{w}$ の分布を示 し, 図-4はこの平均流速 $U_{w}$ とフルード数 $F_{r}=0.2$ の開 水路流の流速 $U_{w(\text { open })}$ との流速差を表したものである. 界面近傍では流下方向と逆向きの風シア一の影響で流速 の落ち込みが見られる. また, 開水路流と比較して界面 付近では主流速は遅くなっているが, 半水深付近では逆 に開水路流よりも主流速が速くなっている. これらの特 




図-3 水層平均流速 $U_{w}$

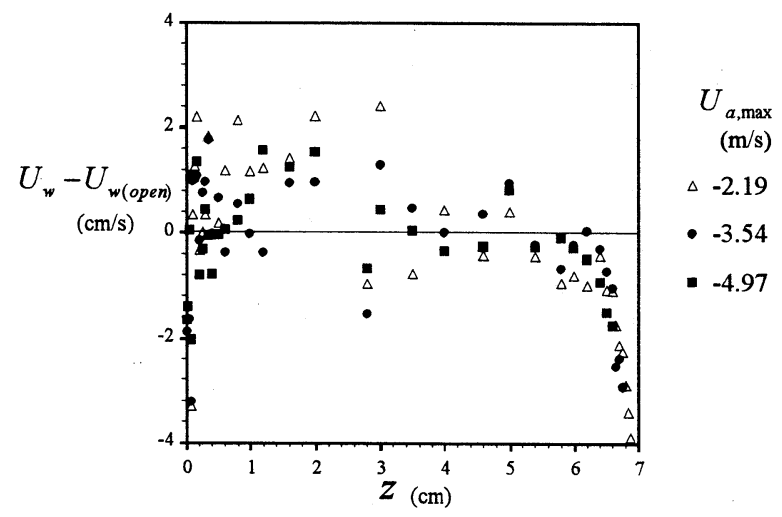

図-4 水層逆流場と開水路との平均流速差 $U_{w}-U_{w(\text { open })}$

性は，鶴谷 ${ }^{5} か ゙$ 逆流場における主流速分布の模式図を提 案しているが，本実験でも同様の傾向を示している.

図-5は同じく水層の平均流速 $U_{w}$ の分布を内部変数表示 したものである. ただし，データは各々図中で上方に 10 ずつ平行移動させている. 図中には次式の対数則および 粘性底層分布を併示した。

$$
\text { 対数則流速分布 } U_{w}^{+}=\frac{1}{\kappa} \ln z^{+}+A
$$

粘性低層流速分布 $U_{w}^{+}=z^{+}$

ここで, $U_{w}^{+} \equiv U_{w} / U_{* b}, \quad z^{+} \equiv z U_{* b} / v_{w}, \quad \kappa$ はカルマ ン定数, $U_{* b}$ は水路底面における摩擦速度, $v_{w}$ は水の 動粘性係数， $A$ は積分定数である. 開水路乱流では $\kappa=0.41, A=5.3$ が推奨值である ${ }^{9}$. 順流場との比較と して既往の研究4) のデータの流速分布も併示した. 逆流 場と順流場では主流速分布にいくつかの違いが見られる. まず，逆流場では順流場で見られたような流速分布の平 昍化領域け見られない，また，逆流場において粘性底層 での流速分布は全ケースを通じて変化はないが，風速の 増加に伴い対数則領域での流速分布において積分定数 $A$ の值が図-5に示すように大きくなる傾向が見られる. これは, 逆流場では開水路と比較して半水深付近より下 の領域で主流速が大きくなっていることによるものと考 えられる.

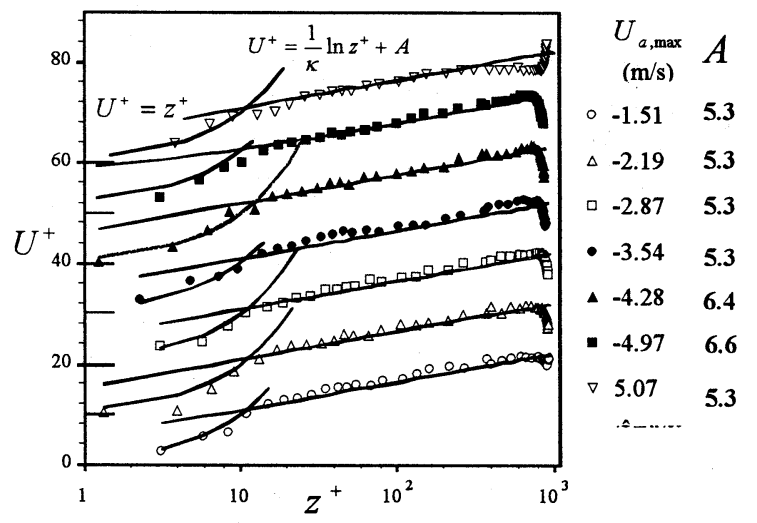

図-5 水層平均流速 $U_{w}$ （内部変数表示）

\section{（2）乱れ特性分布}

\section{（a）乱れ強度}

図一および図-7は水層における流下方向乱れ強度 $u^{\prime}$ および鉛直方向乱れ強度 $v^{\prime}$ の鉛直分布であり，底面摩 擦速度 $U_{*_{w}}$ で無次元化して示したものである. 同図に は鿅津の半理論公式 ${ }^{10)}$ を併示した。

$$
\begin{aligned}
& u_{w}{ }^{\prime} / U_{*_{w}}=2.3 \exp \left(-z / h_{w}\right) \\
& v_{w}{ }^{\prime} / U_{*_{w}}=1.27 \exp \left(-z / h_{w}\right)
\end{aligned}
$$

また, 同図にはRashidi \& Banerje(1990)の逆流場にお ける乱れ強度のデータ（実験条件： interfacial shear rate $\partial U / \partial z=25.2 \mathrm{sec}^{-1}$ ) を点線で併示した. なお，図中 の $\mathrm{Re}_{w}$ は水層におけるレイノルズ数である. 図-8およ び図-9は逆流場と順流場における乱れ強度 $u^{\prime} ， v^{\prime}$ を比 較したものである．なお，順流のデータは既往研究(4)の ものである. 水面が穏やかなケース（REV1〜REV2）で は乱れは界面近傍で若干増加しており，これは既往研究 でも同様の傾向を示している. しかし, 風速が増大し界 面波が発生するケース（REV3〜REV6）では界面で発生 した乱れが半水深以下まで影響を及ぼし，水層全体で大 きな值となっており，これは順流では半水深付近では乱 れが減少する点と大きく異なっている. これは主流速分 布の違いから説明できる. すなわち, 順流では半水深付 近で主流速分布が平坦化しているのに対して, 逆流では 領域全体を通じて流速勾配が大きいことによるものと考 えられる。

\section{(b) レイノルズ応カ}

図-10は水層におけるレイノルバ応力- $-\overline{u v}$ の分布を示 したものである. 図中には次式の三角形分布を併示した.

$$
-\overline{u v} / U_{*_{w}}^{2}=(1-z / h)
$$

また, 乱れ強度と同様, Rashidi \& Banerjee(1990)のデー 夕を点線で併示した。 まず，底面および界面近傍を除き 全ケースを通じてレイノルズ応力は底面付近からほぼ直 線的に減少する傾向が見られる。一方界面近傍について 


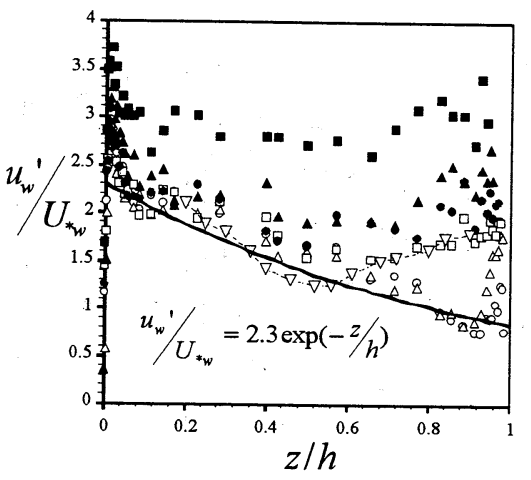

$U_{a, \max } \quad \operatorname{Re}_{w}$

- $-1.51 \quad 18000$

$\Delta-2.19 \quad 18000$

ㅁ -2.8718000

- -3.5418000

- $-4.28 \quad 18000$

- -4.9718000

$\nabla$ Rashidi \& 2500

(1990)

図-6 水層乱れ強度 $u_{w}$

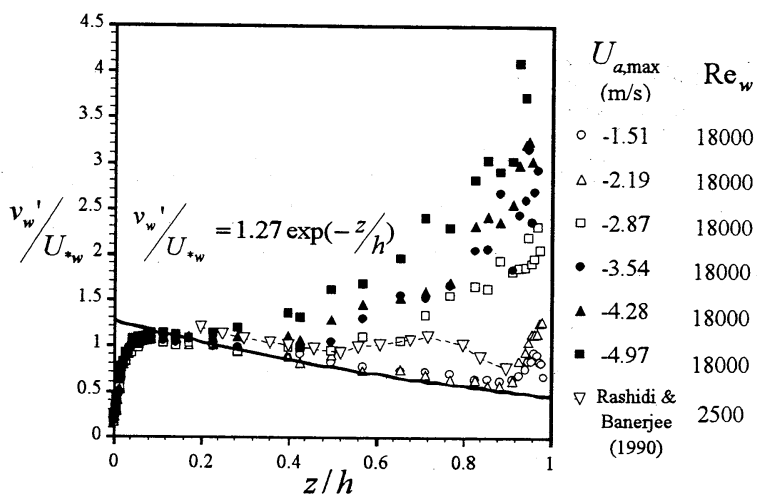

図-7 水層乱れ強度 $v_{w}{ }^{\prime}$

は，水面が穏やかなケース（REV1〜REV2）では負の值 を示しており鶴谷”も同様の傾向を示している.また， 風シアーが大きくなり界面波が発生するケース（REV3 〜REV6）では界面近傍でレイノルズ応力は逆に大きな 正の值を示しておりこれは順流場と同様の傾向を示して いる.

\section{（c）スペクトル解析}

図-11および図-12には逆流場での水層界面近傍点 $(z / h \cong 0.9)$ での主流速変動のパワースペクトル $S_{u} お$ よび水面変動のパワースペクトル $S_{h}$ を示した. 図中の

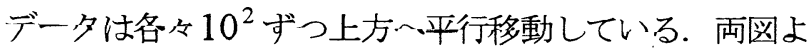
り，1Hz付近において卓越した変動パワーが観察され， これは風波固有の卓越周波数 $f_{p}$ とみなせる. また，順 流場と同様に，スペクトルピークの高周波側には， $f^{-5 / 3}$ が成立する周波数領域が観察され，これは，界面 付近での水の挙動が吹送流による界面せん断流と波によ る回転軌道変動によって構成されることを示唆している. したがって，逆流場でも順流場と同様，風速の増大によ り界面付近の水の動きは開水路による変動から風波流れ の変動一と遷移することがわかる. 図-13は風波が発生

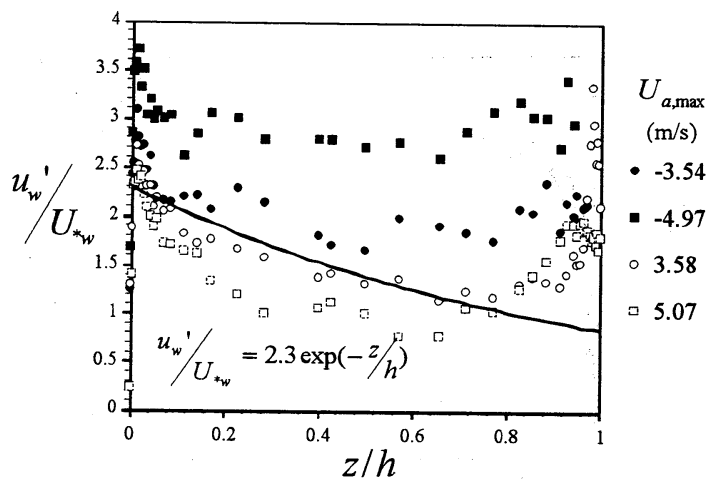

図-8 水層乱れ強度 $u_{w}{ }^{\prime}$



図-9 水層乱れ強度 $v_{w}{ }^{\prime}$

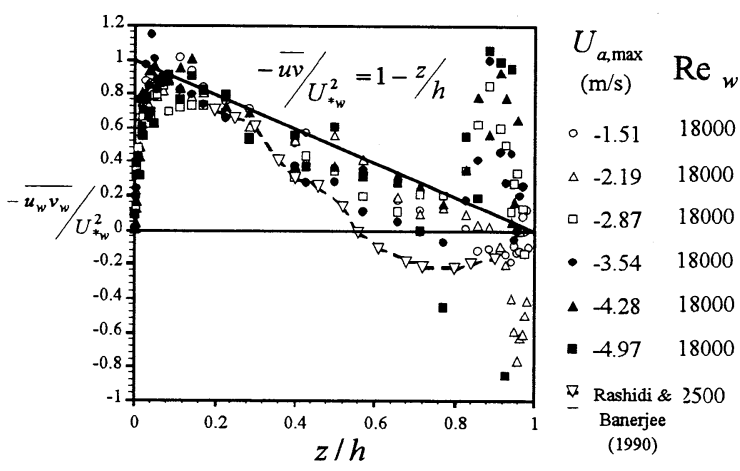

図-10 水層レイノルズ応力 $-{\overline{u_{w} v_{w}}}$

している場合において最大風速 $U_{a, \max }$ に対する順流場 と逆流場における風波の卓越周波数 $f_{p}$ の分布である. 順流場のデータは既往研究4)のものである．逆流場にお ける卓越周波数 $f_{p}$ は順流場のそれに比べ小さくなって いる．また，順流場においては風速が大きくなると卓越 周波数が小さくなるのに対し，この研究では逆流場では 風速が大きくなっても卓越周波数はほとんど変化してい ないが，この点に関しては理由が説明できないので今後 


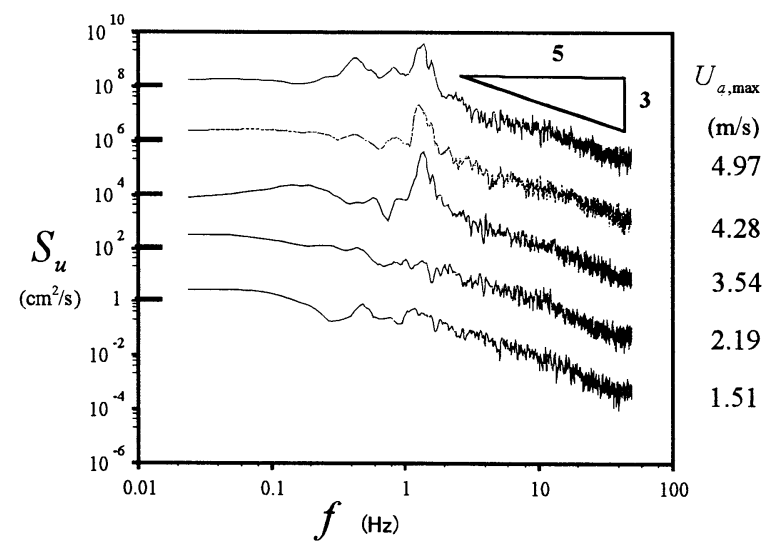

図-11 流速変動パワースペクトル $(z / h \cong 0.9)$

(102ずつ平行移動させて表記)

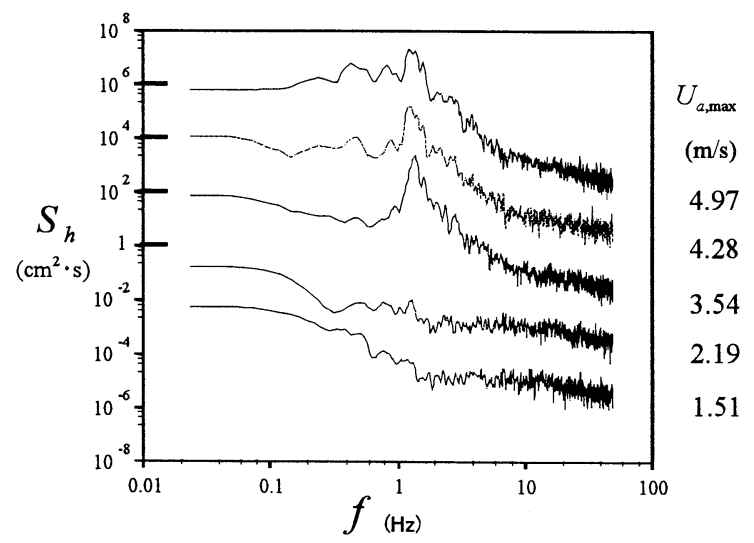

図-12 水面変動パワースペクトル

（102ずつ平行移動させて表記）

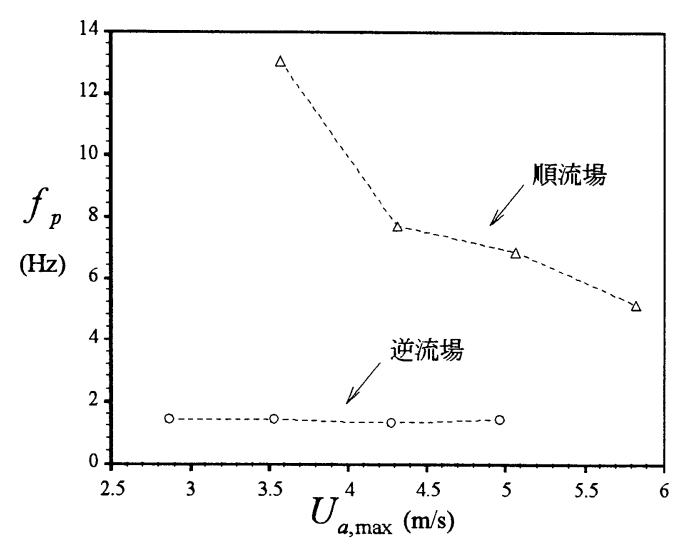

図-13 卓越周波数分布

更なる検討をしていきたい.

\section{（d）水面変動と流速変動との相関}

図-14は空気層界面摩擦速度 $U_{* a}$ に対して水面変動強 度 (水面変動のrms值) $h$ を示したものである. 同図に はChu(1993) $)^{11)}$ の逆流場におけるデータ, および順流場 ${ }^{4}$

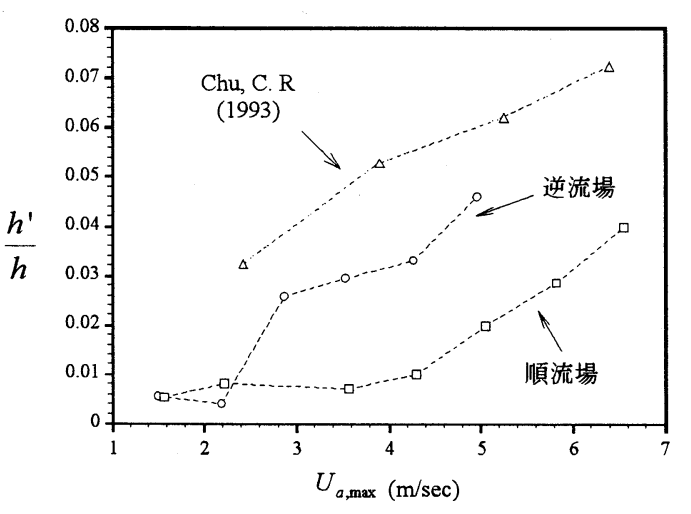

図-14 水面変動強度 $h^{\prime}$

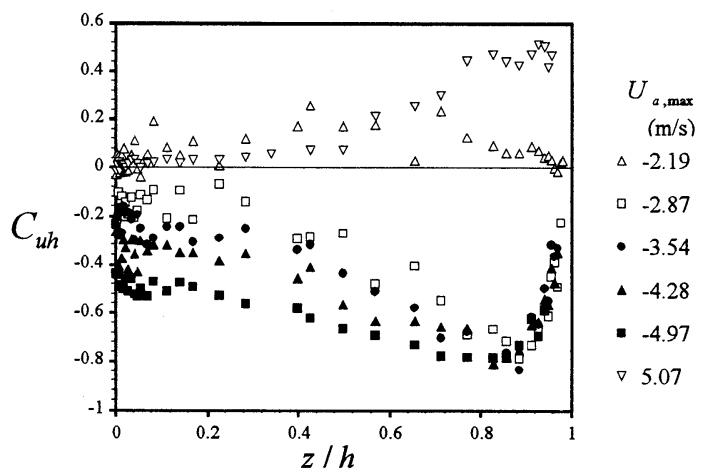

図-15. 水面変動と流速変動の相関係数 $C_{u h}$

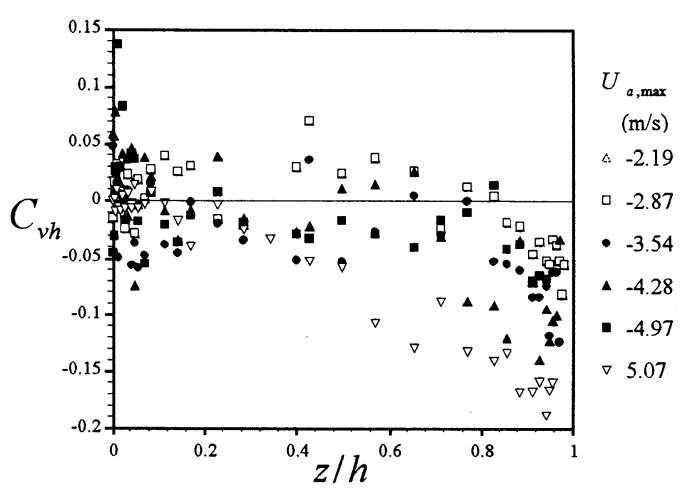

図-16 水面変動と流速変動の相関係数 $C_{v h}$

のデータを併示した．同図より，風波が発生している ケースでは，風速が増大して風シアーが大きくなるにつ れて水面変動は大きくなることが分かる. また, 同じ風 速に対しては順流場より逆流場のほうが水面変動強度は 大きくなっている．図-15および図-16は水面変動 $h(t)$ 之水層流速変動 $u(t), v(t)$ との相関係数 $C_{u h}$ $\left(=\overline{u h} / u^{\prime} h^{\prime}\right), C_{v h}\left(=\overline{v h} / v^{\prime} h^{\prime}\right)$ の鉛直分布を示した ものである. 図には既往研究の順流場における相関係数 を併示している ${ }^{4}$. 逆流場では水面変動が大きくなると $C_{u h}<0, C_{v h}<0$ となり, 正の水面変動 $h(t)>0$ の 


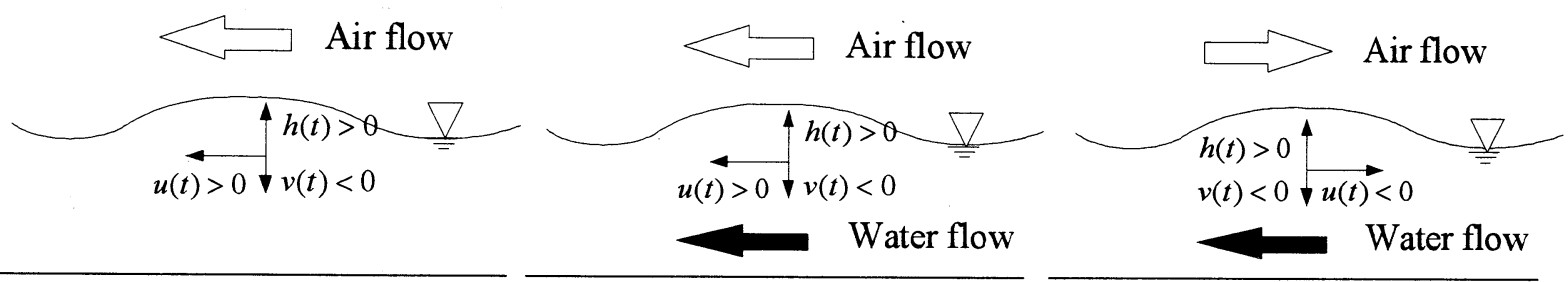

図-17 水面変動と流速変動の模式図 (左図: 風波のみ 中図: 順流場 右図 : 逆流場)

時に $u(t)<0, v(t)<0$ となる. 順流場では相関係数 $C_{u h}$ は正の相関を示しており，順流場と逆流場では逆の 相関関係を示している.このことは図-17の模式図で説 明できる. 風波は空気流の主流速方向を正とすると，正 の水面変動 $h(t)>0$ の時に $u(t)>0, v(t)<0$ とな り，これは水が流れていても界面付近では風波による水 の挙動が卓越する．よって順流場では水流と空気流の主 流速方向が同じ風波のみの流れ場と同じ相関を示し，逆 流場では水流と空気流の主流速方向が逆になるため, $u(t)$ に関して風波場と逆の相関を示すと言える.また, 逆流場において主流速成分の変動 $u(t)$ は風波が大きく なるにつれて水深深くまで負の高い相関を示すが，鉛直 方向成分の変動 $v(t)$ は風速の増大に関わらず界面近傍 を除いてはほとんど相関関係がないことが分かる.

\section{4. おわりに}

本研究は水流と逆向きの風シアーを伴う開水路乱流場 を対象として，レーザー流速計(LDA)で2次元計測を行 い，逆流場における乱れ特性についての検討を実験的に 行ったものである. その結果, 以下の結論が得られた.

1）主流速分布において順流場と逆流場では異なる分 布を示す．また，逆流場においても底面からほぼ 対数則が成立する.

2）乱れの分布について逆流場では風シアーが強くな るにつれ順流場と異なり界面近傍だけでなく半水 深付近でも乱れが大きくなる.これは主流速分布 の影響と考えられる.

3）レイノルズ応力分布については逆流場においても 底面および界面近傍を除き三角形分他を示一。ま た，界面近傍では風シアーが弱い場合では負の值 を示すが，風シアーが強くなると正の值を示す。

4）水面変動について逆流場では順流場と比較して弱 い風速で風波の発生に影響を与える．水面変動と 主流速変動との相関については，界面シアーが大 きい条件では負の相関を示す。

\section{参考文献}

1) Hughes,E.D. and Duffey, R.B.: Direct contact condensation and momentum transfer in turbulent separated flows, JMultiphase Flow, Vol17, No5, pp.599-619, 1991

2) Chu, C.R. and Jirka, G.H.Reaeration in combined wind/steram driven flows, Air-Water Gas Transfer, B. Jahne and E.S,Monahan eds. , AEON Verlag, pp.553-569, 1995

3）鿅津家久・吉田圭介・牛島省 : 水面上に風シアーが存在する 開水路流れ場における水・空気層乱流構造に関する基礎的研 究, 土木学会論文集, No.733/III-63, pp.67-76, 2003.

4）襧津家久・吉田圭介・垂井晃一：水面上に風シアーが存在す る開水路流場における水層乱孔構造と水面変動に関する研究, 水工学論文集, 第48巻, pp.517-522, 2004.

5) 鶴谷広一: 流れに及ぼす風と波の効果について一流速分布、 乱れ強度及び搪散係数の検討一, 昭和59年度 港湾技術研究 所講演会講演集, pp.35-76, 1984.

6) Rashidi, M. \& Banerjee, S.: The effect of boundary conditions and shear rate on steak formation and breakdown in turbulent flows, Phys. Fluids A, Vol2, No.10, pp.1827-1838, 1990.

7）スパラティッド・セリー・田中仁・首藤伸夫 : 波・流れ共存 場における流速分布に関する研究, 海岸工学論文集, 第38巻, pp.6-10, 1991.

8）鶴谷広一・中野晋・柳嶋慎一・松延嘉國 : 逆流中での風波の 発達特性，港湾技術研究所報告，第26巻，第4号，pp.35-56， 1987.

9) Nezu, I and Nakagawa, H: Turbulence in Open-Channel Flows, IAHR-Monograph, Balkema, 1993.

10) 襧津家久 : 開水路乱流の乱れ強度に関吉る研究，土木学会 論文集, No.261，pp.67-76, 1977.

11) Chu, C. R. (1993): Experiments on gas transfer and turbulence structure in free sufface flows with combinod wind/bottom shear, Ph. D Thesis presented to Cornell University.

(2004.9. 30 受付) 